\title{
PREFACE
}

\section{A Flight Formation}

$\mathbb{I}$

first read the phrase "In the Royal Chicano Air Force, we fly below the radar" in the summer of 2000, when I picked up the local newspaper, the Sacramento Bee, and boarded a plane from Sacramento, California, to Williamsburg, Virginia. Having earned my bachelor's degree in American literature, I was moving to the US Southeast to begin my graduate education in the American Studies Program at the College of William and Mary. I planned to study dialect literature and its relationship to African American voices in film.

Preparing for liftoff, I turned to a favorite columnist who commented on various happenings in Sacramento. In an article entitled "Murals Pack a Hidden Punch," the columnist praised the "restoration of the wall murals lining the K Street tunnel between the Downtown Plaza and Old Sacramento" (Graswich 2000). I had never considered the origins of these massive murals, but I learned that Chicano artist Esteban Villa had created one of the murals, and his colleague Juanishi Orosco had created the other one. Villa was mentioned in the column as saying, "Pedestrians will be rewarded if they look deep inside the designs for farm laborers and a farm truck. 'In the Royal Chicano Air Force, we fly below the radar"' (Graswich 2000). Having passed the murals for years, I wondered about the hidden images. I also wondered who or what was the Royal Chicano Air Force (RCAF).

High above the ground, flying toward someplace else, I recalled the moment in José David Saldívar's (1997) Border Matters when he reflects on his education in South Texas. While very much the center of Saldívar's universe, his hometown was also a place "where history began and ended with the master periodizing narratives of the Alamo." Saldívar writes, "I learned all the hard facts about regional hegemony and global colonialism's cultures, for culture, my teachers believed, always lived somewhere else-never in 
our own backyard" (160). In my case, or rather, on my plane, I realized I too believed American culture lived somewhere else. Much like Saldívar, who left South Texas to study American literature at Yale in 1973, I headed to Virginia in 2000 to learn about American culture because I thought "I knew hardly anything about America" (Saldívar 1997, 159). Flying away from the center of my universe, reading an intriguing blurb about hometown murals, I entered a state of Nepantla in the Anzaldúan sense.

"Nepantla" is a Nahuatl word for a "space between two bodies of water, the space between two worlds" (Anzaldúa 1999, 237). ${ }^{1}$ Physically it is a limited space, but according to Gloria Anzaldúa, Nepantla is also conceptually infinite; it is a "space where you are not this or that but where you are changing" (237). A physically confining yet theoretically expansive space, Nepantla perfectly described my in-flight experience. I was deeply engrossed in thought about the RCAF murals-from their narrative potential to the politics of encoded messages in public art. But none of the possibilities excited me. I started time-traveling against the direction of my plane, returning to my adolescence and searching my memory for moments when I had failed to really see the murals (Acconci 1990). I felt uneasy sitting inside a vessel and fastened to a seat that was headed east, then south, while thinking beyond the physical space of the cabin. My discomfort did not stem from a fear that I had made the wrong decision to move away to learn about American culture. Rather, I was in the midst of realizing I had moved away to learn about Chicano/a culture. The RCAF's art history-when the artwork was made and who and what it responded to-began for me in the twenty-first century. The principal question I ask with my anecdote is why I had not heard of the Royal Chicano Air Force, a historic Chicano/a art collective that was native to my region of California. After all, I had obtained all my education, up through my bachelor's degree, in Northern California's public schools. Saldívar's passage about his education in South Texas echoes in the "regional hegemony" that shaped my monocultural vision of America. While I had access to culture, history, and language at home through my family, Chicano/a art, literature, and history were not taught in my public school classrooms, where a particular cultural vision of American art, literature, and history was definitely taught. ${ }^{2}$ My lack of Chicano/a consciousness in 2000 mirrors its absence from the historical consciousness of the United States to date. 


$$
\begin{gathered}
\text { FLYING UNDER } \\
\text { THE RADAR WITH THE } \\
\text { ROYAL CHICANOAIR FORCE }
\end{gathered}
$$


THIS PAGE INTENTIONALLY LEFT BLANK 